\title{
Fear of Forward Guidance*
}

\author{
Alex Isakov, VTB Capital \\ alex.isakov@vtbcapital.com \\ Petr Grishin, VTB Capital \\ petr.grishin@vtbcapital.com \\ Oleg Gorlinsky, VTB \\ gorlinsky@vtb.ru
}

This article is a response to the review of Adrian et al. (2018) by Yudaeva (2018), which summarizes the case of the Bank of Russia against the publication of key rate forecasts, a communication strategy known as conventional forward guidance. We believe that the case in favour of publishing the Bank of Russia'a key rate forecast is at present not stated sufficiently coherently. Our note attempts to fill this gap. Extending the argument put forward by Adrian et al. (2018) we provide a comprehensive review of the working papers, staff notes, and leadership comments related to interest rate expectations and monetary policy communication by four central banks that have had practical experience with the application of conventional forward guidance. We conclude with an evaluation of the validity of the commonly voiced concerns regarding its adoption in Russia, based on the reviewed literature.

Keywords: inflation targeting, Citation: Isakov, A., Grishin, P., monetary policy, central bank communications Gorlinsky, O. (2018). Fear of Forward Guidance. Russian Journal of Money

JEL Codes: E58 and Finance, 77(4), pp. 84-106.

doi: $10.31477 /$ rjmf.201804.84

\section{Introduction}

Monetary policy is a conservative area. New approaches and ideas undergo careful inspection, scrutiny and testing before being considered for adoption. The latest changes to the monetary policy framework in Russia were the transition to a freely floating exchange rate, and an inflation targeting regime in 2014 . This setup is generally considered as preferable, as it allows for a smoother absorption of external shocks. However, such consensus is relatively recent - in the early 1990s the debate regarding the suitability of flexible (and, ultimately, floating) exchange rate arrangements for emerging markets was far from being settled (see

\footnotetext{
* We are grateful to Nadezhda Ivanova and Olga Kuvshinova (of the Bank of Russia) for their invaluable help and support while working on this paper, and also to Alexey Khazanov (of Boston College), Nikolay Frolov and Pavel Pikulev (of Sberbank) who kindly shared their ideas and comments.
} 
the review by Frankel, 2003). Interestingly, even when the consensus shifted firmly in favour of floating exchange rates (e.g. see the discussion in Parrado, 2004) the monetary authorities released their grip on FX market only grudgingly - a phenomenon dubbed by Calvo and Reinhart (2000) as 'fear of floating'. Central banks characterised by 'fear of floating' are those for which the declared flexibility of the exchange rate arrangement is believed to be higher than what is effectively practised.

Central banks' transparency with regards to monetary policy and their adoption of forward guidance in their communications in particular, we believe, suffer from a similar pattern of reluctant adoption. 'Fear of forward guidance', then, is a situation in which the central bank would acknowledge and indeed promote transparency as a general principle of its communication policy, but in practice would limit the amount of disclosure regarding its intentions for future changes in the policy rate.

Before proceeding any further, we need to acknowledge that forward guidance is an umbrella term covering a diverse set of communication strategies, which can be broadly divided into three groups: ${ }^{1}$

- 'General policy comments', as per Yudaeva (2018), are verbal qualitative descriptions of the future monetary policy stance;

- 'Conventional forward guidance', as per Adrian et al. (2018), implies publication of the central bank's forecast of the policy rate path or paths;

- 'Commitment', as per Smith and Becker (2015), includes conditional and unconditional commitments to a published interest rate trajectory.

This article focuses exclusively on the second type of forward guidance and, more precisely, it is a response to the review of Adrian et al. (2018) by Yudaeva (2018). The latter summarises the case of the Central Bank of Russia (CBR) against the publication of key rate forecasts. Extending the argument put forward in Adrian et al. (2018), we provide a comprehensive review of the working papers, staff notes, and leadership comments related to interest rate expectations and monetary policy communication by four central banks that have had practical experience with the application of conventional forward guidance.

To reiterate, this is a wide review with a narrow goal. We will comprehensively review the working papers and other relevant bodies of work related to interest rate expectations and monetary policy communications by the central banks of New Zealand, Sweden, Norway and the Czech Republic. However, the primary question is narrow: did the private sector experience confusion between

\footnotetext{
${ }^{1}$ We do not claim our classification is exhaustive or our naming convention universal. For instance, Gavin et al. (2013) calls interest rate path announcement with commitment 'Odyssean forward guidance', while Filaček and Matějů (2014) extend this Greek naming convention and calls the publication of the central bank's interest rate forecast without commitment to this path 'Delphic forward guidance'.
} 
guidance and commitment, or did it demonstrate a decrease in independent efforts to understand economic developments?

The note is structured as follows: in the next section we will open the topic up for further discussion by examining evidence of mismatches between the CBR's interest rate policy outlook and that of the market. This will be accomplished by looking at the evidence provided by public surveys. This exercise is challenging because the CBR's interest rate projections are unavailable, which means we are limited to the outcomes of monetary policy meetings and CBR's own communication on the subject. In the third and main section we review the literature generated by research conducted at the four central banks deemed to be in the 'avant-garde on inflation targeting' by Adrian et al. (2018): the Reserve Bank of New Zealand (RBNZ), Norges Bank (NB), Sverige Riksbank (SR) and the Czech National Bank (CNB). In order to ensure a comprehensive review is carried out, we have consulted all working papers, public staff notes and statements by the banks' leadership available online, related to the interest rate expectations of the markets and to the management of such expectations, for monetary policy purposes, by the central bank. These archives typically span from the early 1980s to the present. The depth of the banks' experience with conventional forward guidance is also substantial, ranging from 20 years for the original adopter, RBNZ, to 10 years for the CNB. In the fourth section we review the case against conventional forward guidance, as summarized in Yudaeva (2018), and comment on the salience of the concerns raised by the practising central banks. We also highlight the approaches that the aforementioned central banks used to avoid confusion between guidance and commitment. The last section concludes.

\section{Motivation}

Increasingly, clear communication on behalf of the central bank is seen as essential for an efficient monetary policy, a point highlighted both in Adrian et al. (2018) and Yudaeva (2018). In its official statements, the CBR (Bank of Russia, 2017) has stated that, in order to build confidence in its policy and reduce and anchor infaltion expectations, it will increase its communication transparency and be more open about the measures it employs to achieve the goals of the monetary policy.

The costs generated by the bias in the interest rate expectations of the public and the markets are of the same nature as those arising from unanchored inflation expectations. Both are factores influencing the real interest rates, which in turn drive essential decisions regarding borrowing and saving, and capital allocation. This means that if inflation expectations are excessively high or interest rate expectations excessively low, then monetary conditions will be easier than what is consistent with the central bank's goal and the bank would have to tighten its monetary policy further or for longer, than in the case of wellcoordinated expectations. The reverse is true for excessively low inflation or high 
interest rate expectations, which may lead to the bank repeatedly undershooting to the inflation target, resulting in less buoyant economic activity. ${ }^{2}$

How relevant is this issue to Russia? For the purposes of this discussion, it is useful to rely on the suggestion of Blattner et al. (2008) to distinguish between short-term and long-term predictability when assessing the clarity and efficiency of a central bank's communication. Central banks' longer-term predictability is inherently difficult to measure, especially when the numerical guidance on the interest rate path is not available. Thus, we first review the evidence provided by the market's ability to foresee the CBR's decisions in the short term.

To assess the short-term predictability of the monetary policy, we rely on Bloomberg survey data of financial analysts. This data is most suitable for the purpose because the platform essentially allows for changes to the estimate submitted up to the moment of the announcement of the rate by the Board of Directors, and thus it excludes the possibility that the rate submitted rate is different because of events occuring between the time of submission and the publication of the decision.

Figure 1a. Share of correct estimates of the policy rate decision: New Zealand

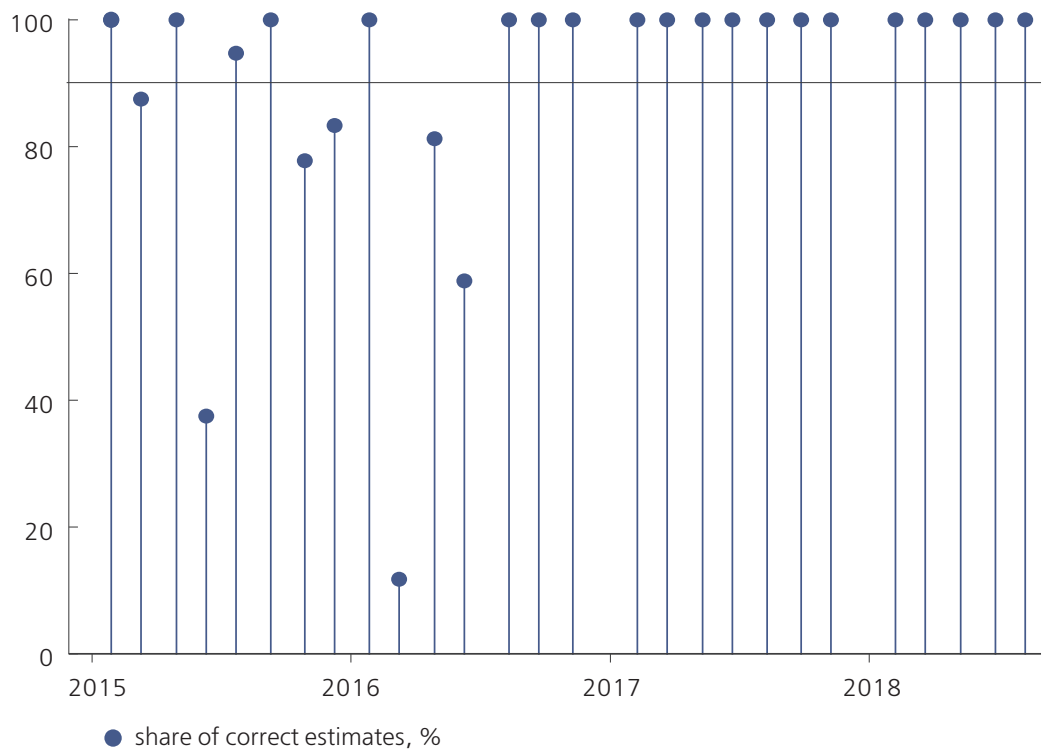

Source: Bloomberg

We review the data for January 2015 - September 2018, which is the period characterised by a floating exchange rate regime, excluding the initial shock

\footnotetext{
2 The ability of the central bank to influence longer term interest rates are implied by the "expectations theory" of the yield curve, e.g. see Cox et al. (2005). Empirical tests of this hypothesis are not uniformly supportive, i.e. Roush (2007) finds that they hold in case of monetary policy shocks, and are rejected when shocks stem from aggregate demand.
} 
of Q4 2014. During this period, 29 Board of Directors' meetings took place. According to the Bloomberg data, on average, $65 \%$ of the estimates submitted correctly predicted the Board's decision regarding the key rate. In five cases (January 2015; April 2015; March 2017; April 2017; December 2017) the decision was expected only by $1 / 4$ or less of those surveyed. In two cases (January 2015; December 2017), the decision was completely unexpected by the forecasters.

Figure $1 \mathbf{b}$. Share of correct estimates of the policy rate decision: Russia

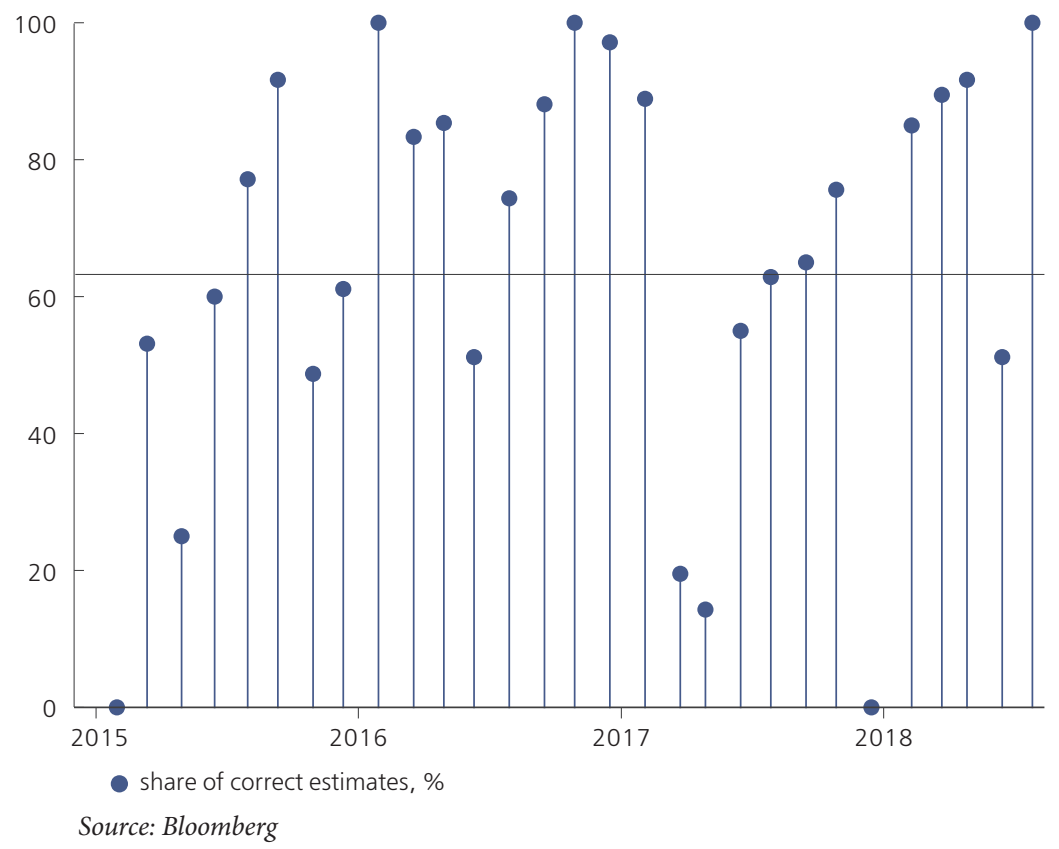

To determine how typical these results are, it is useful to compare the average shares of correctly submitted estimates for 2015 - 2018 for Russia and for a country where the central bank had already adopted conventional forward guidance: $65 \%$ (Russia) vs 90\% (New Zealand).

Longer-term predictability is more important from a monetary policy implementation perspective, and more costly - if the mismatch persists from a capital allocation perspective. However, it is also not possible to reliably evaluate it in the absence of published rate forecasts by the central bank. An exception would be when the central bank itself decides to comment on such divergences.

Such a case was registered in 2016, as documented in Yudaeva (2018), when the CBR identified an appreciable divergence between the CBR's internal and market interest rate forecasts. This prompted the CBR to declare that it will be clearer in its communications and announce a commitment to not revise its interest rate for several months. Given the still relatively recent implementation of inflation 
targeting, even this single episode of divergence between the expectations of the central bank and those of the market should serve as an early lesson.

We believe that the costs of such a mismatch deserve more in-depth study. The gravity of the issue regarding the management of interest rate expectations cannot be less serious than that of the management of infaltion expectations, and is potentially even more consequential.

\section{Interest rate expectations and their management: notes from the avant-garde}

The focus of this review is exclusively central banks' experience with conventional forward guidance (CFG). This means that it omits forward guidance as a commitment to the interest rate path. This strand of literature is concerned with examining the suitability of commitment at the zero lower bound (ZLB), which is not immediately relevant for Russia.

The scope of the review includes all public working papers, staff notes and statements made by the banks' leadership and available online related to interest rate expectations of the markets and their management for monetary policy purposes by the four aforementioned central banks, which have practical experience with implementation of the regime.

Table 1. Adoption of inflation targeting (IT) and rate guidance

\begin{tabular}{l|cc} 
Central bank & IT since... & CFG since... \\
\hline Reserve Bank of New Zealand & 1989 & 1997 \\
\hline Norges Bank & 2001 & 2005 \\
\hline Sverige Riksbank & 1995 & 2007 \\
\hline Czech National Bank & 1997 & 2008 \\
\hline
\end{tabular}

Source: Clinton et al., 2017.

Regarding the literature on conventional forward guidance, in the late 2000s Norges Bank (Qvigstad, 2009) called the publication of the projected paths for the central bank's policy 'the new frontier in central bank communication' and 'high-priority area for future research', but lamented that, at the time, it had only been practiced in a few countries and for merely a few years. The next section takes stock of the evidence regarding the publication of projected paths that we possess one decade later.

Though the results of our reviews of the evolution of central banks' thinking on influencing interest rate expectations will be detailed below, we believe it would be useful at this point to briefly outline our impression of a typical evolution pattern we have detected in such thinking:

1) Identification: the central bank issues working papers that document the methodology used to extract monetary policy expectations from available financial instruments and/or surveys (i.e. Söderlind and Svensson, 1997); 
2) Evaluation 1: working papers that attempt to assess which degree the monetary policy expectations of the markets are aligned with those of the monetary authorities by looking at surveys or at the volatility of the money market rates around the time of the central bank's decision announcements. Such studies usually find a relatively low predictability of the monetary policy and a scope for more transparent communication (i.e. Bulir et al., 2007);

3) Implementation: to address the challenge posed by monetary policy surprises, the central bank opts to adopt conventional forward guidance (i.e. Czech National Bank, 2008);

4) Evaluation 2: typically 2 - 3 years after implementation of forward guidance, working papers start to evaluate its effects on the short-term interest rate volatility, as well as its power to shape the yield curve (i.e. Drew and Karagedikli, 2008).

This is a highly stylised scheme. There are cases where two steps (usually, identification and evaluation) are packaged into one research note. However, we believe it is useful to organise the evolution of ideas on interest rate expectations and on the central bank's communication into steps, in order to discern patterns such as the above.

\subsection{Forward guidance research at the RBNZ}

The year 1997 is commonly cited (e.g. in Clinton et al., 2017) as marking the start of conventional forward guidance in New Zealand. This, however, might be misleading for the modern reader, and we think that a fully modern monetary policy implementation system was not put in place by the RBNZ until 1999. ${ }^{3}$ The first review of interest rate expectations is found in Krippner (1998), who looks at

\footnotetext{
${ }^{3}$ The monetary policy framework has been materially different: the level of reserves of the banking sector with the central bank serving as an operational instrument for achieving the operational target was formulated in terms of an interest and exchange rate synthetic indicator called the monetary conditions index (MCI). Interested readers may refer to the discussion paper of the Reserve Bank of New Zealand (1997b), which notes that '... the Reserve Bank set out a proposal to alter key technical aspects of monetary policy implementation, involving a shift from targeting settlement cash balances to targeting the overnight interbank cash interest rate. After consulting with market participants, we were persuaded that the risks with the proposed change might not be sufficiently outweighed by the benefits.' The initial proposal and detailed discussion are available in the aforementioned paper (Reserve Bank of New Zealand, 1997a).

A fully modern system of monetary policy implementation was not put in place until 1999, when the RBNZ explained, as cited in Archer et al. (1999), that it would be using the official cash rate to set the stance of the monetary policy, because 'we increasingly recognised the unpredictability of the relationship between the quantity of settlement cash and overall monetary conditions'. According to the note, the 'Official Cash Rate system is more transparent and easier to understand than the previous regime. [...] The setting of the official cash rate clearly and unambiguously expresses the desired stance of monetary policy, and between reviews the actual cash rate will stay close to the Official Cash Rate' Even following the implementations of this step, the initial announcement stated that the indicative conditional forward path for monetary policy, contained in the projections included with Monetary Policy Statements will continue to be expressed in MCI terms, which it did only for a brief period. This suggests that the more appropriate dating of the implementation of conventional forward guidance in New Zealand would be 1999 rather than 1997.
} 
interest rate futures. While he finds that futures provide an unbiased estimate of the future money market rates, the root mean square forecast error is close to 1 pp for periods as short as 90-day forecast. Krippner (2002) proposes an approach to extracting policy rate expectations from the interbank lending yield curve. $\mathrm{He}$ finds a positive term premium and makes suggestions about the identification of the underlying expectations regarding official rates by the banks.

Drew and Karagedikli (2008) explore the communication policy of the RBNZ in order to find out whether interest rate forecast publications help financial markets better anticipate a central bank's reaction to incoming data and not to overreact to macroeconomic data surprises. In particular, they use high frequency data to explore whether data and monetary policy surprises affect longer-term interest rates. They conclude that forward rates tend to increase in response to positive inflation or GDP surprises, anticipating the central bank's reaction. They add that, while some of their contemporaries argued that transparent communication risks non-credibility, as policy-makers might not always follow through with prior commitments if conditions change sufficiently, their findings suggest that this concern is misplaced.

Fukač (2008) explores the monetary policy consequences of heterogeneous expectation formation. He concludes that, if the private sector's beliefs are well-coordinated (if 'knowledge is homogeneous'), then a central bank can decrease inflation volatility and speed up the learning of its reaction function, if it demonstrates inflation aversion. The power of the central bank to decrease inflation volatility if beliefs are heterogeneous is lower. Thus, they conclude that the central bank should coordinate interest rate expectations if it is able to do so.

Delbruck et al. (2008) provide an in-depth overview of the evolution of the RBNZ's forecasting and modelling toolkit. They underline the role of the publication of the central bank's endogenous interest rate path, which creates a natural focus for summarising changes in a projection relative to the previous quarter. Discussions structured around the review of the expected path of the policy rates help communicate how the medium-term outlook has changed and what has driven such a change. Notably, they provide the decomposition of contributions of various shocks to the reviewed interest rate trajectory.

Detmers and Nautz (2012) provide the most recent review of the RBNZ's experience with forward guidance. Their reviw notes, that in order to achieve a highly efficient monetary policy implementation, the central bank needs to shape market expectations about the future path of short-term rates. This understanding lead the RNBZ to adopt a quantitative forward guidance strategy, which includes publication of long-term interest rate projections. The authors also show how the global financial crisis has changed the efficiency guidance, and conclude that the role of interest rate projections for futures rates has decreased, i.e. their estiamtes 
show a sharp decline in the size and significance of all coefficients related to interest rate projections. They hypothesise that these findings might be related to: 1) data issues, i.e. unstable risk premiums, which make futures rates unsuitable proxies for market expectations; 2) deterioration of the central bank's forecasting precision. Indeed, the RNBZ's self-assessment (Reid, 2016) supports the latter view and reports that the RBNZ has 'underpredicted' the level of the trade weighted exchange rate, which led to the undershooting of the tradable and headline inflation rates.

The conclusion arising from the RBNZ's experience is that conventional forward guidance helps coordinate the private sector's expectations more efficiently, accelerates the learning of the central bank's reaction function and decrease interest rate volatility. However, the ability of the central bank to manage interest rate expectations depends on the lack of persistent bias in its projections. If and when such biases arise, they will gradually diminish the power to coordinate expectations. We believe that this decline in the attention paid to the central bank' communications would be present irrespectively of the type of communication chosen: biased inflation forecasts would be detrimental to the central bank's credibility even if it limits itself to general comments.

\subsection{Forward guidance research at Norges Bank}

The evolution of the approach to monetary policy communication at Norges Bank (NB) offers another interesting glimpse into debates that are considered settled today.

In particular, prior to the adoption of conventional forward guidance, the monetary policy reports of the central bank not only omitted the bank's interest rate projections but, also, all projections assumed a constant policy rate. This meant that the need for adjustment of the policy stance was judged on the basis of deviation of inflation from the target level, according to such projections. Gjedrem (2001) documents this debate in his address, noting that several academics had argued in favour of shifting from an unchanged to an optimal interest rate scenario as the basis for inflation projections, because the central bank itself does not regard an unchanged interest rate as the most probable scenario. Thus, other projections published by the central bank, including those relating to inflation, are indeed different from what the central bank in fact expects.

In an attempt to improve its communications, NB switched to conditioning its forecasts on the market-implied policy rate expectations, as Gjedrem (2005) notes, and started to comment on how the official expectations differ from those of the market. A typical commentary regarding this is provided by Norges Bank (2005a).

The next milestone was NB's adoption of conventional forward guidance announced in a statement (Norges Bank, 2005c) that noted the published interest rate path provides a reasonable balance between the objectives of monetary policy. 
Norges Bank (2005b) added two important comments. First, it highlighted that the motivation behind the adoption of conventional forward guidance was provided by NB's evaluation of the accuracy of market expectations of money market rates. The estimated average deviation of the market implied rates and actual rates for horizons in excess of one year exceeded 2.5 pp for $1999-2005$. Second, it provided the criteria that Norges Bank uses to evaluate the coherence of the projected interest rate path. The report presents six such criteria:

- The interest rate must be set so that inflation is stabilised near the target within a reasonable time horizon, normally $1-3$ years.

- The inflation gap and the output gap should be in reasonable proportion to each other until they close, and normally not be positive or negative at the same time further ahead.

- Interest rate developments should result in an acceptable inflation and output, also under alternative assumptions regarding the model of the economy.

- The interest rate should be changed gradually so that we can assess the effects of interest rate changes and other new information about economic developments.

- Interest rate setting must take into account changes in property prices and credits.

- The interest rate path should be cross-checked with some simple monetary policy rules, and systematic and substantial deviations from these simple rules should be explained.

Qvigstad (2006) discusses these points in greater depth. Interestingly, he provides a useful definition of transparency in citing the European Central Bank's president Duisenberg, who suggests that a central bank is transparent if its external communication reflects its internal deliberations.

Holmsen et al. (2008) review three years of experience with publication of the interest rate projections and find evidence of reduced volatility in market interest rates on the days with interest rate decisions. They show that the change in the 12-month money market interest rate on the day after the interest rate decision announcement nearly halved after the introduction of the endogenous monetary policy path in 2005. These results suggest that communicating policy intentions improve the market participants' understanding of the central bank's reaction pattern.

The paper also reviews two typical concerns regarding conventional forward guidance. The first one is voiced by Goodhart (2001) and Mishkin (2004), who believe that it would be more difficult for a monetary policy committee to agree on a path of future interest rates. Holmsen et al. (2008) see no evidence of the practical relevance of this concern. Additionally, theoretical literature explores 
cases where there is a penalty for deviating from the forecasts in the central bank's loss function. Typically, the finding is that this is suboptimal. Holmsen et al. (2008) underscore that their experience suggests that deviating from the announced interest rate forecast is not perceived as costly to the policy makers at $\mathrm{NB}$, as long as reasons for it are provided.

Mirkov and Natvik (2016) bring this statement to the test and asks whether announced forecasts influence actual policy decisions. They examine the data provided by the RBNZ and NB and find some evidence of reluctance to deviate from previously announced interest rate paths. However, such dependence only extends as far as one quarter ahead, while forecasts older than one quarter have no effect on the current policy rate. These results, at least in the case of NB, are hardly surprising given that the criteria for an appropriate policy path listed by Norges Bank (2005b) explicitly state that the interest rate should normally be changed gradually.

The most recent evaluation of experience with conventional forward guidance are provided by Brubakk et al. (2017) for both Norway and Sweden. They find that Norway's experience suggests that surprise revisions in the policy path significantly affect the yield curve, even as far as 10 years ahead. These effects are persistent. However, they note that central banks' ability to shape the yield curve is not limited to conventional forward guidance, and information beyond what is revealed through the published interest rate path can have a sugnificant impact. Additionally, the paper emphasises that the market understands that the guidance is issued conditionally based on the knowledge available and on the views of the committee, while the market's own assumptions may differ from those of the central bank.

The bottom line is that NB adopted conventional forward guidance based on the understanding that it will provide a clearer communication strategy and appreciation of sizeable and persistent mismatches between the central bank's interest rate and the market's interest rate expectations. According to Holmsen et al. (2008), publication of the interest rate path allows market participants to gain information about the sign of the future interest rate decisions, but may have less information about the size. Evaluation of the accumulated experience suggests that the guidance issued by the central bank is able to shape most of the yield curve, but the private sector continues to form independent expectations regarding future economic developments, which preserves a diversity of outlooks.

\subsection{Forward guidance research at Sverige Riksbank}

An examination of the working papers produced at Sverige Riksbank provides another example of how thinking about modern inflation targeting evolved. In particular, just two decades ago Palmqvist (1998) explored the costs of disclosing 
the level of the inflation target, noting that the signal is perceived as costly to the central bank because the central bank commits to bringing the inflation rate in line with the announcement.

The earliest working paper focused on interest rate expectations is that of Söderlind and Svensson (1997), which provides a methodological overview of the literature. The first original contribution, made by Faust and Svensson (2001), explores the implications of varying degrees of transparency of the monetary policy for the policy's implementation and for social welfare. The study links transparency with the level of effort that is required of the public in order to deduce central bank intentions from observables. The authors conclude that high transparency induces the bank to follow a policy closer to the socially optimal one. Taken to the extreme, complete transparency is generally socially beneficial, but frequently not in the interest of the central bank. The authors are able to show that high transparency improves the public's inferences about the central bank's goals, and reduces errors in inflation expectations.

Ellingsen and Söderström (2001) explore the effects of unexpected interest rate changes on the yield curve. They find that the response of the market depends on the causes of the monetary policy shock: 1) if the reason is the better informed call by the central bank of the higher future inflation, then the yield curve shifts higher; 2) if the unexpected increase in the rate is due to the shift in the preferences of the central bank in favour of more stable inflation, then only the shorter-term rates increase, while the longer-term interest rates decline. Ellingsen and Söderström (2004) take this line of inquiry further by exploring the effects of monetary policy surprises on the long-term part of the yield curve. In a standard setting, longerterm yields would not respond to short-term surprises in the setting of key rates by the central bank, but in practice they are found to be sensitive to them. The authors show that this behaviour is consistent with the fact that the central bank possesses private information on the future path of inflation. This can help reproduce the excess longer-term yields' volatility. We believe that these findings may imply that, unless the central bank communicates with the markets and shares its private information, then even in a situation where monetary policy is credible, longerterm interest rates would remain relatively volatile and, thus, the term premium would remain elevated.

Andersson et al. (2002) look at the impact of the central bank's communications on the shape of the yield curve. Authors extend the scope of such communications to include speeches and press releases. They conclude that unexpected changes in the repo rate are the most important factors behind the movements of the short end of the yield curve. The authors go further and note that Riksbank's monetary policy is rather unpredictable in the short run, which might suggest a problem with transparency. Their diagnosis of the cause of this disconnect is somewhat 
original: they believe that much of the lack of predictability of the repo rate is due to the mismatch between the frequency of changes optimal policy rules imply.

Söderlind et al. (2003) ask an interesting question: if the central bank is following a rules-based policy and if the markets are good at forecasting fundamentals (GDP, inflation), then by implication they should also be good at forecasting the policy rate. They examine surveys of professional forecasters and financial market data and conclude that forecasts of fundamentals are relatively precise, but monetary policy decisions are less predictable, which was earlier established by Andersson et al. (2002), who found that both survey data and market expectations had a low predictive power. Researchers proceeded to test whether monetary policy is predictable based on theoretical statistical models and concluded that interest rate changes are not predictable according to the VAR model. One plausible reason for such an outcome may be that monetary policy responds to a wider set of factors than those included in the typical formulation of the monetary policy rule. This would mean that even the publication of the central banks model of the economy or its policy rule would be unlikely to align its policy decision with market expectations - thus, another way of communication is needed to fully convey its interest rate outlook.

Berg et al. (2004) revisit the theme of the policy rate predictability based on simple rules and the central bank's own forecasts. They conclude that on average deviations are not very large, but also highlight that Riksbank occasionally deviates from the simple rules, driven by the factors absent from those rules. They suggest extending the scope of the published data beyond the forecasts of fundamentals and urge policy-makers to reveal the 'secrets of the temple' in order to increase the public's understanding of the monetary policy strategy.

Evidence of the limited predictability of the monetary policy leads Riksbank's governor (Ingves, 2006) to note that one possible future development could be to follow in the footsteps of central banks such as those of New Zealand and Norway, and actually publish Riksbank's own views on future interest rates, instead of using market expectations as a basis. Later, the Duty Governor expanded on Sverige Riksbank's position (Rosenberg, 2007) by stating: 'I think it is unavoidable that a central bank sometimes surprises analysts when publishing its own forecast for the policy rate. The future is uncertain and different analysts may at times have vastly differing perceptions of economic developments. Publishing a forecast for the repo rate means that the central bank more clearly reports its view of future developments than with earlier more mechanical assumptions of the interest rate. At the same time, it means that the central bank risks being exposed to criticism to a greater extent. Even if this is the case, it is my firm opinion that it is better to go the whole way and publish a forecast for the repo rate. The advantages of an own interest rate path clearly outweigh the disadvantages'. 
Riksbank's monetary policy report for 2007 (Sverige Riksbank, 2007) marked the adoption of conventional forward guidance. The report highlighted the risks of confusing commitment with guidance, and attempted to prevent this confusion by including three alternative interest rate paths implied by different economic outlooks.

Svensson (2009b) explores various approaches to the evaluation of the consistency of monetary policy and finds that, although historical deviations of inflation from the target level could be a valid metric, it requires an exceedingly long time-series. On the other hand publication of the central bank's policy rate forecasts can reveal monetary policy reaction function in real time. The author provides several case studies for Riksbank and concludes that the market both anticipated the repo-rate path reasonably well, and that expectations after the announcements were reasonably aligned with the new path.

Did the publication of the interest rate paths make verbal communication obsolete? Apel and Grimaldi (2012) explore whether information can be extracted from monetary policy meeting minutes, which can help forecast future decisions. Their results are supportive of this assumption and confirm the market's awareness of the conditionality of interest rate forecasts. They show that markets are able to extract these conditions from the central bank's verbal statements.

While central banks can more effectively steer interest rate paths using forward guidance, usually some discrepancy between the market-implied outlook remains. De Graeve and Iversen (2017) explore this discrepancy for the Swedish cash rate and report that monetary policy should not disregard deviations between announced and market forward rates, as they can have real effects. This disparity between the market outlook regarding rates and the central bank's forecasts may be reasonable. As Alsterlind (2017) shows in his study of the four central banks reviewed in this article, all central banks have overestimated the actual policy rate on average since 2007. The reason behind the bias, as the authors suggest, has been a global decline in core rates.

The latest assessment of the efficiency of the central bank's control over the interest rate expectations is provided in Ahl (2017). The author concludes that Riksbank has the ability to use the repo-rate path to affect market expectations up to between one and three years, noting that the effect is less than one-to-one and decreasing with the horizon. Another interesting finding is that the impact of a path surprise is larger if it narrowes the current gap between the previously announced path and market expectations, while surprises that widen the gap are more readily dismissed by the markets.

The bottom line is that the adoption of forward guidance at Sverige Riksbank has been driven by careful study of the interest rate expectations and an appreciation of the uncertainty that surrounds monetary policy decisionmaking from the economy's point of view. In particular, milestone findings by 
Söderlind et al. (2003) show that even the private sector's relatively tight handle on financial developments leaves the monetary policy unpredictable. Post-adoption evaluations show the ability of the guidance to steer longer maturity rates in the direction deemed appropriate from a monetary policy perspective.

Sverige Riksbank's Deputy Governor Svensson summarised his assessment of the central bank's experience stating that not to publish the interest rate forecast would be to hide the most important information (Svensson, 2007).

\subsection{Forward guidance research at the Czech National Bank}

The earliest paper on market expectations regarding the CNB's monetary policy interest rate was published by Hlušek (2002). The author uses the interbank interest rate and Forward Rate Agreement (FRA) data to identify probabilities of interest rate decisions. Hlušek then applies the model to five consecutive monetary policy meetings between November 2001 and March 2002. These case studies suggest that the market-favoured outcome coincided with the decision taken by the CNB only in one out of five studied cases. The note concludes with two observations regarding the post-decision revisions of the market-implied policy interest rate expectations: 1) the market does not adjust its monetary policy outlook if the central bank's decision meets its expectation; 2) a surprising interest rate cut leads to a substantial decrease in the probability of additional cuts in the future. These effects may or may not match theintentions of the central bank.

These results demonstrated a need for a more transparent communication policy. As Kotlán and Navrátil (2005) note, since the launch of the new forecasting methodology in July 2002, the CNB limited itself to verbal comments on the forecast-consistent interest rate trajectory. Their paper reviews the results of Hlušek (2002) and reports that approximately 3/4 of the CNB's decisions were in line with longer-term money market expectations, but over the sample available to researchers the repo rate expectations show an upward bias.

Fukač (2006) explores the consequences of the heterogeneity in expectations for the monetary policy. In particular, the paper devises a New Keynesian business cycle model in which monetary policy is driven by the central bank's own forecasts, while the rest of the economy depends on the expectations of the private sector. He concludes that if knowledge and beliefs differ across various segments of the private sector, then to achieve a preferable equilibrium the central bank needs to focus on 'knowledge homogenization'.

Bulir et al. (2007) explore how and whether verbal communication helps the public to understand the monetary policy outlook based on a panel of six countries over 2000 - 2005. They note that about one-third of all monetary policy decisions did not match expectations. This means that monetary policy decisions did not match prior communication and could not be explained away by inflation surprises. 
Driven by this cumulative evidence of uncertainty regarding the monetary policy, the $\mathrm{CNB}$ decided to start publishing the interest rate forecasts, as stated in Filáček et al. (2007), noting that this should increase its accountability and credibility and improve the efficiency of its monetary policy. In 2008, the CNB announced its transition to conventional forward guidance (Czech National Bank, 2008).

The CNB's approach to preventing confusion between guidance and commitment was to publish a chart showing its own historical policy rate forecasts as compared with actual outcomes. The chart was titled 'The actual interest rate path often differs from the CNB forecasts'. The CNB's reports also started to provide fan charts emphasizing that its forecast is not a single path, but distributions of outcomes.

Based on the 2008 working paper, Bohm et al. (2012) explore a tangent theme: what determines the 'favourableness' of press coverage of the monetary policy decisions between 2000 and 2007. One of their findings is relevant: they identify a high correlation between the indicator of surprising decisions and the indicator of the release of the new forecast. This means that before transition to conventional forward guidance, markets had a limited ability to foresee the revisions of the economic outlook by the central bank and monetary policy implications of such revisions.

Two years after the introduction of conventional forward guidance, Filáček and Saxa (2012), based on the 2010 working paper, explore changes in the diversity of the financial analysts' forecasts depending on the distance from the publication of the central bank's forecasts. They find that the standard deviation of the distribution of private forecasts is smallest immediately after the release of the CNB's forecast, which suggests that such publications are an effective coordinating mechanism. They also explore the impact of interest rate publication on the efficiency of the central bank's communication and find that publication of the interest rate forecast significantly increases the ability of the central bank to anchor inflation expectations.

Horvath et al. (2011) review another innovation: disclosure of voting records of the monetary policy committee. They find evidence of voting records to be informative about future monetary policy, concluding that this provides a case for publishing the records.

The price puzzle in conventional forward guidance setting is explored in Filaček and Matějů (2014). They report that it is possible that in the presence of information asymmetry, monetary policy surprises by the central bank can have paradoxical effects on inflation expectations: if the central bank raises the key rate by more than the markets expected, then the markets' expectation of the inflation may increase too. This may happen if markets believe that the central bank is better positioned to understand future inflation. This result is in line with Filaček and Saxa (2012), who suggest that policy rate path publication improves the central bank's ability to coordinate expectations. 
The recent summary of the CNB's experience with conventional forward guidance is summed up by Clinton et al. (2017). The authors note that the Czech experience shows that the published interest rate path has the potential to shape market expectations, supporting the transmission of the monetary policy. They also emphasise a caveat, stating that the efficiency of such communication might be undermined if the central bank provides alternative scenarios that point strongly in a direction different from a baseline.

The bottom line is that the CNB's case provides more evidence of the ability of the central bank to promote monetary policy transmission efficiency through publication of the indicative paths of the policy rate. The key mechanisms are the coordination of the private sector's expectations and the latter's deeper understanding of the central bank's decision-making patterns. CNB's work also adds an important reminder, that monetary policy surprises may induce paradoxical responses, i.e. hawkish surprise might increase inflation expectations, which underscores the importance of expectation management.

\section{Notes on concerns regarding conventional forward guidance}

Yudaeva (2018) provides a lucid and concise summary of practitioners' concerns regarding the publication of the policy rate path:4 'The publication of an interest rate path, even subject to reservations, could, in our view, be perceived exactly as a commitment, thus not only reducing policy flexibility but also shifting the focus of the discussion away from its end goal, inflation, to interim goals'.

We see here two distinct concerns:

1) Confusion: published interest rate paths would be perceived as commitment, not projections, based on the central bank's assumptions regarding external environment, fiscal policy, etc.;

2) Lower effort: the publication of the interest rate forecasts will reduce the efforts made by the market and public to understand macroeconomic developments independently, as they move towards to an excessive reliance on the CBR's forecast.

The reviewed literature provides three key conclusions regarding the problem of confusion.

\footnotetext{
${ }^{4}$ Wider academic literature expresses concerns regarding other potential challenges related to publication of the interest rate path, i.e. (Gosselin et al., 2008) notes that opacity may be creative and raise welfare if the private sector is able to systematically predict central bank inflation forecast errors. Walsh (2007) notes that 'optimal' transparency depends on the relative size of cost and demand shocks, and Baeriswyl and Cornand (2011) finds a trade off between transparency and the weight on output stabilisation. We focus on the policy makers' perspective in this note and thus emphasise the view in Yudaeva (2018), which provides a clear summary of such a perspective.
} 
First, none of the cases provides evidence that the perceived commitment problem, as it is called by Clinton et al. (2017), has in fact materialised. Why? This leads us to the second conclusion.

Second, each of the central banks studied devised solutions to lower the confusion risk, which proved robust in all cases. They used the following strategies to convey the conditionality and uncertainty of the policy rate path:

1) Publish historical forecasts: in its first report containing conventional forward guidance, the $\mathrm{CNB}$ published a chart that superimposed its policy rate path onto historical forecasts, thus clearly showing that there can be discrepancies between the two;

2) Provide alternative scenarios: in its first report containing guidance, the NB provided three alternative economic outlooks with corresponding paths of the policy rate, explicitly showing the conditionality of the latter and providing additional data that would help the public to understand the reaction function of the central bank;

3) Provide confidence intervals: all central banks show confidence intervals around the policy rate forecast, showing that the indicative path is in fact a series of distributions and thus reflecting the uncertainty related to both various shocks and, quite simply, the mechanics of the economy.

Third, confusion between conditional guidance and unconditional commitment is not unique to explicit numerical guidance, but can also occur when the central bank decides to limit communication to general policy comments (see Table 2). In fact, the reviewed literature shows that the predictability of policy is lower for periods when central banks limit communication to verbal statements and increases when they decide to supplement it with explicit policy rate paths.

Table 2. Guidance: general comments vs. explicit path

\begin{tabular}{lcc|c} 
Communication & $\begin{array}{c}\text { Can be perceived } \\
\text { as commitment? }\end{array}$ & $\begin{array}{c}\text { Susceptibility } \\
\text { to misinterpretation }\end{array}$ \\
\hline General policy comments & Yes & High \\
\hline $\begin{array}{l}\text { Conventional forward } \\
\text { guidance }\end{array}$ & Yes & Low \\
\hline
\end{tabular}

Source: authors.

Regarding the risk that the change in the focus of the monetary policy from its strategic goal to its instrument - the policy rate - the reviewed literature suggests that guidance can help coordinate inflation expectations, which is one of the key goals of monetary policy. Yet expectations remain diverse and market participants do hold outlooks regarding economic developments that are different from that of the central bank. Clinton et al. (2017) note that market reaction to macroeconomic news was not reduced by the introduction of published policy rate paths in 2007, controlling for the effect of the ZLB. 
The power of the central bank to coordinate expectations is not constant but depends on its performance. For example, studies of the effects of guidance on the shape of the yield curve after the Great Recession found that it has declined, typically linking this observation to persistent undershoots in inflation and, by implication, emerging upward bias in rate guidance. Regarding forecast precision Holmsen et al. (2008) provide a useful comment: it is not possible to make forecasts that prove to be accurate in all respects, but by revealing errors, central banks provide a basis for improving the analysis.

The body of work review suggests three related concerns, which might arise with the publication of the policy rate forecast.

First, if policy makers are themselves overly attached to previously published forecasts, then guidance can result in excessive interest smoothing. The reviewed literature finds some evidence of interest rate smoothing, but such 'path dependence' does not exceed one quarter. Policy-makers themselves are demonstrably aware of the need to avoid excessive interest rate smoothing, i.e. Gjedrem (2001) notes that even if needed changes in the interest rates were to surprise the markets, that should not be an obstacle for adjusting the policy stance: '[...] a desire for predictability must not precede the demand for an interest rate setting that the central bank deems to be correct. The expectations of other economic agents must not control the setting of interest rates'.

Second, Goodhart (2001) and Mishkin (2004) suggest that it can be difficult for a monetary policy committee to agree on a whole path of future interest rates. This criticism might have been more salient in an era when central banks used to condition their published forecast on the assumption of the unchanged policy rate or market implied path, but is less applicable today, when the interest rate is endogenous and is agreed upon at each decision round, even if not published. Svensson (2009a) suggests an iterative procedure to coordinate the views of the members of the policy committee, but says that, in practice, the need for this has never arisen.

Lastly, recent papers (e.g. Filaček and Matějů, 2014) have argued that there might be risks associated with some unintended effects of signalling, i.e. if the market believes that the central bank is better informed about future inflation, then surprise tightening of the monetary policy may in fact increase inflation expectations, as the market corrects its inflation outlook. We believe that, while this mechanism is plausible, there is scarce evidence that the costs of the increase in inflation expectations offset the benefits of the tighter control of the yield curve.

\section{Conclusion}

The primary question that this review attempts to address is whether the central banks that opted to publish their policy rate forecasts experienced the drawbacks noted in Yudaeva (2018): confusion with a commitment to the 
published path, and a reduction in the private sector's effort to develop an economic outlook. We find no evidence supporting these concerns. Instead, the literature provides several robust approaches to diminishing these risks: publication of the historical forecasts, producing alternative scenarios, and wrapping the baseline in confidence bands.

Additionally, the reviewed body of works by the four central banks which have published policy rate forecasts for the last 10 to 20 years suggests that conventional forward guidance may increase the predictability of monetary policy and the efficiency of the transmission mechanism, accelerate the learning of the central bank's reaction function by the private sector, and enhance the ability of the markets to understand policy implications of new data in real time, thus reducing interest rate volatility.

However, the literature suggests that the efficiency of the guidance may vary (i.e. decline if the central banks' forecasts develop a bias), warning against excessive interest rate smoothing, and emphasising that policy rate path publication does not supplant verbal guidance, which remains relevant and closely watched.

\section{References}

Adrian, T., Laxton, D. and Obstfeld, M., eds. (2018). Advancing the Frontiers of Monetary Policy. Washington, DC: International Monetary Fund.

Ahl, M. (2017). How Big is The Toolbox of a Central Banker? Managing Expectations with Policy-Rate Forecasts: Evidence from Sweden. Sveriges Riksbank Working Paper, N 339.

Alsterlind, J. (2017). Common features in short maturity interest rate forecasts. Sverige Riksbank Staff Memo, June.

Andersson, M., Dillén, H., Sellin, P. (2002). Monetary Policy Signalling and Movements in The Swedish Term Structure of Interest Rates. In: Market Functioning and Central Bank Policy. BIS Papers, N 12, pp. 268-297.

Apel, M. and Grimaldi, M. (2012). The Information Content of Central Bank Minutes. Sveriges Riksbank Working Paper, N 261.

Archer, D. J., Brookes, A. and Reddell, M. (1999). A Cash Rate System for Implementing Monetary Policy. Reserve Bank of New Zealand Bulletin, 62(1).

Baeriswyl, R. and Cornand, C. (2011). Transparency and monetary policy effectiveness. Annals of Economics and Statistics, 103/104, pp. 175-194.

Bank of Russia (2017). Monetary Policy Guidelines 2018-2020. Available at: http://www.cbr.ru/content/document/file/48477/on_18-eng.pdf (accessed on 3 September 2018).

Berg, C., Jansson, P. and Vredin, A. (2004). How Useful are Simple Rules for Monetary Policy? The Swedish Experience. Sveriges Riksbank Working Paper, N 169.

Blattner, T. S., Catenaro, M., Ehrmann, M., Strauch, R. and Turunen, J. (2008). The predictability of monetary policy. ECB Occasional Paper, N 83.

Bohm, J., Kral, P. and Saxa, B. (2012). The Czech National Bank's Monetary Policy in the Media. European Journal of Political Economy, 28(3), pp. 341-357. 
Brubakk, L., Ter Ellen, S. and Xu, H. (2017). Forward Guidance through Interest Rate Projections: Does It Work? Norges Bank Working Paper, N 6.

Bulir, A., Smidkova, K. and Kotlan, V. (2007). Inflation Targeting and Communication: Should the Public Read Inflation Reports or Tea Leaves? Czech National Bank Working Paper, N 14.

Calvo, G. A. and Reinhart, C. M. (2000). Fear of Floating. NBER Working Paper, N 7993.

Clinton, K., Hledik, T., Holub, M. T., Laxton, M. D. and Wang, H. (2017). Czech Magic: Implementing Inflation-Forecast Targeting at the CNB. IMF Working Paper, N 17/21.

Cox, J. C., Ingersoll Jr, J. E. and Ross, S. A. (2005). A Theory of the Term Structure of Interest Rates. In: S Bhattacharya, G. Constantinides eds., Theory of Valuation, 2nd ed. World Scientific Publishing Co, pp. 129-164.

Czech National Bank (2008). Inflation report / I 2008.

De Graeve, F. and Iversen, J. (2017). Central Bank Policy Paths and Market Forward Rates: A Simple Model. Journal of Money, Credit and Banking, 49(6), pp. 1197-1224.

Delbruck, F., Dunstan, A., Hargreaves, D., Lienert, A., Pepper, H. and Sleeman, C. (2008). The Evolution of the Forecasting and Policy System (FPS) at the Reserve Bank of New Zealand. Reserve Bank of New Zealand Discussion Paper, N 19.

Detmers, G.-A. and Nautz, D. (2012). The Information Content of Central Bank Interest Rate Projections: Evidence from New Zealand. Reserve Bank of New Zealand Discussion Paper, N 3.

Drew, A. and Karagedikli, Ö. (2008). Some Benefits of Monetary Policy Transparency in New Zealand. Reserve Bank of New Zealand Discussion Paper, N 1.

Ellingsen, T. and Söderström, U. (2001). Monetary Policy and Market Interest Rates. American Economic Review, 91(5), pp.1594-1607.

Ellingsen, T. and Söderström, U. (2004). Why are Long Rates Sensitive to Monetary Policy? Sveriges Riksbank Working Paper, N 160.

Faust, J. and Svensson, L. (2001). Transparency and Credibility: Monetary Policy with Unobservable Goals. International Economic Review, 42(2), pp. 369-397.

Filáček, J., Komárek, L. and Král, P. (2007). Why Central Bankers Should Disclose Interest Rate Forecast. Czech Journal of Economics and Finance, 57(11-12), pp. 558-576.

Filáček, J. and Matějů, J. (2014). Adverse Effects of Monetary Policy Signalling. Czech National Bank Working Paper, N 13.

Filáček, J. and Saxa, B. (2012). Central Bank Forecasts as a Coordination Device: Evidence from the Czech Republic. Czech Economic Review, 6(3), pp. 244-264.

Frankel, J. A. (2003). Experience of and Lessons from Exchange Rate Regime in Emerging Economies. NBER Working Paper, N 10032.

Fukač, M. (2006), New Keynesian Model Dynamics under Heterogeneous Expectations and Adaptive Learning. Czech National Bank Working Paper, N 5.

Fukač, M. (2008). Heterogeneous Expectations, Adaptive Learning, and Forward-Looking Monetary Policy. Reserve Bank of New Zealand Discussion Paper, N 7.

Gavin, W. T., Keen, B. D., Richter, A. and Throckmorton, N. (2013). The Limitations of Forward Guidance. Federal Reserve Bank of St. Louis Working Paper, N 38D.

Gjedrem, S. (2001). Monetary Policy, Forecasts and Market Communication. Speech] The Norwegian School of Management, 7 June. 
Gjedrem, S. (2005). Experiences with Inflation Targeting in Norway and Other Countries. [Speech] The Norwegian School of Management, 7 June.

Goodhart, C. (2001). Monetary Transmission Lags and the Formulation of the Policy Decision on Interest Rates. Federal Reserve Bank of St. Louis Review, July/August, pp. 165-182.

Gosselin, P., Lotz, A., Wyplosz, C. et al. (2008). The Expected Interest Rate Path: Alignment of Expectations vs. Creative Opacity. International Journal of Central Banking, 4(3), pp. 145-185.

Hlušek, M. (2002). Estimating Market Probabilities of Future Interest Rate Changes. Czech National Bank Working Paper, N 2.

Holmsen, A., Qvigstad, J. F., Røisland, Ø. and Solberg-Johansen, K. (2008). Communicating Monetary Policy Intentions: The Case of Norges Bank. Norges Bank Working Paper, N 20.

Horváth, R., Šmídková, K. and Zápal, J. (2011). Central Banks' Voting Records and Future Policy. IES Working Paper, N 37.

Ingves, S. (2006). Inflation Targeting - the Swedish Framework and Experiences. [Speech] Reserve Bank of India, Mumbai, 15 November.

Kotlán, V. and Navrátil, D. (2005). The CNB's Policy Decisions: Are They Priced in by the Markets? Czech National Bank Research and Policy Notes, N 1

Krippner, L. (1998). Testing the Predictive Power of New Zealand Bank Bill Future Rates. Reserve Bank of New Zealand Discussion Paper, N G98/8.

Krippner, L. (2002). Extracting Expectations of New Zealand's Official Cash Rate from the Bank-Risk Yield Curve. Reserve Bank of New Zealand Discussion Paper, N DP2002/01.

Mirkov, N. and Natvik, G. J. (2016), Announcements of Interest Rate Forecasts: Do Policymakers Stick to Them? Journal of Money, Credit and Banking, 48(5), pp. 901-920.

Mishkin, F. S. (2004). Can Central Bank Transparency Go Too Far? NBER Working Paper, N 10829.

Norges Bank (2005a). Inflation Report I/2005. Reports from the Central Bank of Norway, N 1.

Norges Bank (2005b). Inflation Report III/2005. Reports from the Central Bank of Norway, $\mathrm{N} 4$.

Norges Bank (2005c). Norges Bank Increases the Interest Rate by 0.25 percentage point to 2.25 per cent. Norges Bank Press Release, 2 November.

Palmqvist, S. (1998). Why Central Banks Announce their Objectives: Monetary Policy with Discretionary Signalling. Sverige Riksbank Working Paper, N 78.

Parrado, E. (2004). Inflation Targeting and Exchange Rate Rules in an Open Economy. IMF Working Paper, N 04/21.

Qvigstad, J. (2006). When does an Interest Rate Path "Look Good"? Criteria for an Appropriate Future Interest Rate Path. Norges Bank Working Paper, N 5.

Qvigstad, J. F. (2009). Comment on Lars E. O. Svensson's Lecture "Policy Expectations and Policy Evaluations: The Role of Transparency and Communication". [Speech] The Conference "Ten Years of Riksbank Independence", Stockholm, 11 September. 
Reserve Bank of New Zealand (1997a). Monetary Policy Implementation and Signalling: a Discussion Document. Reserve Bank of New Zealand Bulletin, 60(2), pp. 111-120.

Reserve Bank of New Zealand (1997b). Monetary Policy Implementation and Signalling: The Review and Decision. Reserve Bank of New Zealand Bulletin, 60(3), pp. 21-217.

Reid, G. (2016). Evaluating the Reserve Bank's Forecasting Performance. Reserve Bank of New Zealand Bulletin, 79(13), pp. 3-14.

Rosenberg, I. (2007). Monetary Policy and the Riksbank's Communication. [Speech] Swedbank, Stockholm, 8 October.

Roush, J. E. (2007). The Expectations Theory Works for Monetary Policy Shocks. Journal of Monetary Economics, 54(6), pp. 1631-1643.

Smith, L. A. and Becker, T. (2015). Has Forward Guidance been Effective? Federal Reserve Bank of Kansas City Economic Review, 100(3), pp. 57-78.

Söderlind, P., Söderström, U. and Vredin, A. (2003). Taylor Rules and the Predictability of Interest Rates. Sveriges Riksbank Working Paper, N 147.

Söderlind, P. and Svensson, L. (1997). New Techniques to Extract Market Expectations from Financial Instruments. NBER Working Paper, N 5877.

Svensson, L. (2007). Monetary Policy and the Interest Rate Path. [Speech] Danske Bank, Stockholm, 22 August.

Svensson, L. (2009a). Transparency under Flexible Inflation Targeting: Experiences and Challenges. Sveriges Riksbank Economic Review, N 1, pp. 5-44.

Svensson, L. (2009b). Evaluating Monetary Policy. NBER Working Paper, N 15385.

Sverige Riksbank (2007). Monetary Policy Report 2007:1.

Walsh, C. E. (2007). Optimal Economic Transparency. International Journal of Central Banking, 3(1), pp. 5-36.

Yudaeva, K. (2018). Frontiers of Monetary Policy: Global Trends and Russian Inflation Targeting practices. Russian Journal of Money and Finance, 77(2), pp. 95-100. 